\title{
Designing with nature in landscape architecture
}

\author{
D. Dagenais \\ School of Landscape Architecture, Faculty of Environmental Design, \\ University of Montréal, Québec, Canada
}

\begin{abstract}
Two conceptual problems can be identified with the ecological design/design with nature paradigm in landscape architecture. The first is that the nature with which landscape designers are working is manifold in its expression. Researchers as well as philosophers who have studied ecological concepts, theories and conservation practices contrast ideas of nature as a collection of objects (a nature of biodiversity), to ideas of nature as process (a nature of ecosystems, energy transfers, and biogeochemical cycles). In fact, in the same way that conservation of biodiversity implies interventions akin to gardening, designing with biodiversity is very much compatible with garden and landscape design. A collection of taxons, that is specie and cultivar richness, is readily visible and representable. And in fact, growing a collection of plant taxons, whether displayed formally or informally, has been very much part of the history of gardens, long before the present legitimate interest in promoting biodiversity. In the second conceptualization of nature, nature can be understood as a force, a process, sometimes irrespective of the species or number of species involved. This is the nature that is implied in ecological engineering and in design based on natural community succession etc. Designing with such a nature raises the second question: the problem of the representation of the time involved in any process, in landscape in particular, since all theses processes take place in a time frame that exceeds our contact with the landscape. Didactic to poetic descriptions of processes occurring in the landscape or garden become the only way to acknowledge and represent the passage of time.
\end{abstract}

Keywords: ecological design, landscape architecture, Idea of nature, biodiversity, ecological processes, succession. 


\section{Introduction}

Since 1960, the growing social demand for ecology [1] has permeated the practice of landscape architecture. Most practitioners and observers agree that the current paradigm in landscape architecture of designing with nature is predominantly informed by the science of ecology [2]. This general statement ignores two conceptual problems. The first is that nature as informed by ecology is manifold in its expression. The second is that the very representation of time, especially the time required for ecological processes to take place, is somewhat incompatible with both the time frame of our contact with the landscape and the inherently spatial essence of landscape design. This article will discuss, first, how the varied and sometimes opposite views of ecological nature impact on nature conservation and landscape design and, second, why and how landscape architecture succeeds in designing for biodiversity but struggles with designing with ecological processes.

\section{The multiple natures of ecological nature}

Researchers, philosophers and historians have identified a series of fundamental theoretical oppositions in ecology, [3] such as the opposition between determinism and probabilism [4], equilibrium and change [5] or reductionism and holism [6] (otherwise named merological and holological by Odum [7]). These oppositions can be regarded as oppositions in the idea of nature itself. One of these oppositions has been repeatedly noted in ecology, in nature conservation in particular, namely the contrast between nature as a collection of objects, the nature of biodiversity, and nature as process, the nature of ecosystems, energy transfers and biogeochemical cycles.

Authors do not agree on the proper dividing line between ecology subdisciplines regarding that opposition. In Current Normative Concepts in Conservation, Callicott et al. [8] name the two opposite views of nature in ecological science: compositionalism and functionalism. It should be noted that these authors recognize the existence of a continuum between these two poles. Compositionalism includes population and community biology and aims to conserve specie composition and biological diversity. E. O. Wilson is one famous representative of that school of thought. Functionalism, on the other hand, is informed by thermodynamics and is mainly concerned with preserving ecosystem functions. H. T. Odum and all those involved in ecological engineering and ecosystem research would be considered major proponents of that vision. White and Bratton [9] consider emphasis on community and ecosystem preservation as part of a process-oriented approach, while emphasis on population and species conservation is considered a species (biodiversity)oriented approach. Henderson [10] opposes two conceptions of nature conservation: the English and the North American (American and Canadian). The first is be characterized by its commitment to preserve diversity, rare species and landscapes - with the corollary of somewhat strong interference with processes, while the other would be reluctant to intervene. Quoting numerous 
other authors, Cooper [11] distinguishes reserves for biodiversity from wilderness reserves within his four-type typology of nature reserves in Britain. Swart et al. [12] also differentiate an arcadian biodiversity approach in seminatural landscapes from a wilderness approach. As nature conservation resembles landscape architecture in that it implies using knowledge of nature to achieve specific goals. Oppositions between types of interventions identified in nature conservation might then be relevant to landscape architecture.

\section{Biodiversity}

The term 'biodiversity', a contraction of the phrase "biological diversity," was coined in 1985 by Dr Walter G. Rosen [13]), but became known to the public through the 1986 National Forum on BioDiversity sponsored by the National Academy of Science and the Smithsonian Institution, both US organizations. Literally, biodiversity means the diversity of living things. The Convention for Biodiversity (CB) [14] signed in 1992 includes the following definition, which does not mention gene diversity per se although the latter is explicitly referred to in other texts (e.g.: description of the 2008 International Day for Biological Diversity [15]): "Biological diversity" means the variability among living organisms from all sources including, inter alia, terrestrial, marine and other aquatic ecosystems and the ecological complexes of which they are part; this includes diversity within species, between species and of ecosystems."

Although technically, indices of species diversity often integrate corrections for sample size, evenness, rarity of species and other considerations, biodiversity of species equates most often plain species richness whether in conservation literature [16] or in peoples' or landscape designers minds [17]. The concept of species richness could be defined as the number of species present in a given area. However, ecologists or landscape architects themselves do not agree on the species that should be included when assessing the species richness of a specific area. Some discuss the opportunity to include non-indigenous species [18], while for others introduced (exotic) species should be excluded [19, 20]. The convention on biodiversity does explicitly include domestic species as valuable genetic resource material for agriculture. In this case, certain exotic introduced species are thus included in biodiversity [21]. However the CB does not formally recognize urban biodiversity or mention ornamental plants, which is, nevertheless, considered by some as valuable biodiversity [22].

The promotion of biodiversity in its broader meaning has gained support from landscape designers both in their discourse and their praxis [23]. "Diversity is the most commonly cited concept applied to the use of herbaceous plants in public green areas," noted German landscape architect Heiner Luz [24] in a thematic issue of Topos, the European Landscape Magazine, devoted to designing with plants. We postulate that biodiversity in its broader meaning has gained the adherence of gardeners and garden and landscape designers for three reasons. First, the diversity of plant and animal life can be readily recognized by human beings on a morphological basis whether or not there is perfect congruence with taxonomical species [25, 26]. Biodiversity has been 
traditionally valued and cared for in the landscape and in gardens for subsistence, spiritual, aesthetic, status or other reasons [27]. Second, biodiversity, at least plant species richness per area, is, readily representable and visible in the space of the plan or in the materiality of the landscape or garden. (In fact, actual biodiversity results from a process, that of speciation, however it is generally not understood as such by nature conservationists or landscape designers [28]).

The third reason for the enthusiasm for biodiversity within the landscape and garden design world is that gardening and garden design have a long tradition of cultivating the greatest possible number of species. The garden paradise of King Cyrus the Great was described as the receptacle of "everything that is beautiful and good in nature," by Xenophon's Socrates [29]. In more recent history, the practice of plant collection was popular among European gardeners after the prolific introduction of exotic plants from European colonies [30, 31]. At the turn of last century, the renowned garden designer Gertrud Jekyll [32] wrote in her introduction to her 1891 Wood and Gardens: "Some find their greatest pleasures in collecting as many plants as possible from every source." Great nonbotanical gardens renowned for their rich variety of plant species abound [33].

\section{Ecological processes}

The idea of nature as process, as understood in conservation biology, proves less compatible in landscape architecture than a nature of parts. In fact, if ecological processes are left unchecked, as in the wilderness approach of conservation biology, in the end all design will be obliterated. A formerly designed landscape would then become indistinguishable from a so-called natural landscapes. This is rarely the aim of landscape architecture [34]. Furthermore, designing with a nature of process might conflict with the goal of maintaining maximum biodiversity, as noted by Henderson [34] and Cooper [35]. Nevertheless, some ecological processes or ecosystem functions have received particular attention in recent landscape architecture practice. These include energy (biomass) transfer, water and nutrient cycles and succession, probably because these processes use materials familiar to landscape architecture: vegetation, water and soil.

\section{Biodiversity versus succession: a design with nature dilemma}

In a floristically diverse design, ecological processes such as competition and succession will eventually reduce the desired biodiversity in number of species or the presence of rare species. Through competition, a meadow or border can be taken over by a better-adapted species. Maximum biodiversity would require keeping these species in check [37]. The progressive transformation over years or centuries of bare soil or an abandoned field into a forest is the classic example of plant succession. However maximum biodiversity is generally not associated with climax or the end point of the process but with intermediate stages of succession Therefore periodic disturbances (grazing, cutting, burning etc) are necessary to maintain maximum plant and sometimes animal biodiversity $[38$, 
39]. In fact, in some instances, great biodiversity is associated with so-called semi-natural landscapes precisely because human intervention has prevented succession in these landscapes [40]. A well-known example is grazing by domestic animals [41].

As mentioned above, in absolute terms, processes such as plant succession could even be preserved or staged without taking particular species or communities or their diversity into consideration. In the blunt words of LouisGuillaume Le Roy [42], a renowned Dutch landscape designer, "For anyone who thinks and works ecologically, the most important aspect is the management of energy (...) Which plants are included in the system is in essence unimportant." The management of energy referred to by Le Roy, probably inspired by the ecological thermodynamics developed by Odum [43], involves the production of vegetative biomass on a derelict site named the Ecocathedral. Le Roy has brought construction debris to this site since 1970 and has let vegetation take hold of the structures formed from this debris. The Ecocathedral is projected to last until the year 3000 [44], fig. 1. That project is probably as close as one can get to a landscape architecture based solely on the idea of nature as process with the explicit rejection of the idea of nature as parts. Most of the time, designers' writings do not express such a clear choice.

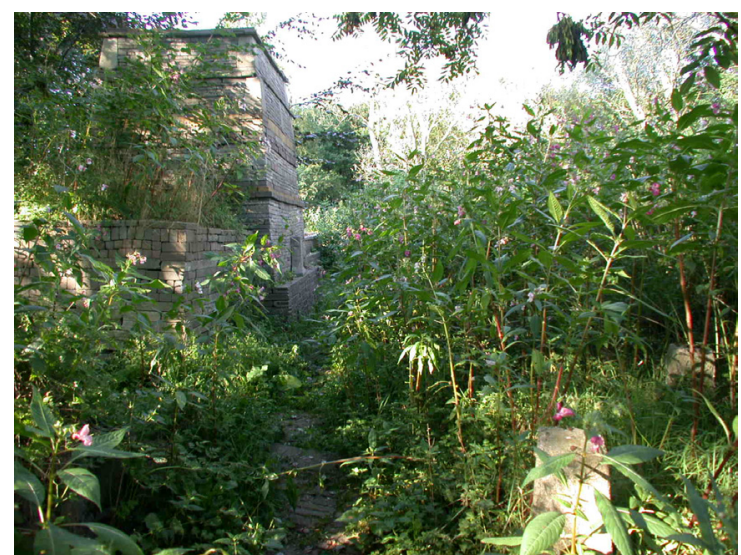

Figure 1: $\quad$ Ecocathedral, Mildam, Netherlands. Photo: Luc Lévesque.

In a book called The Dynamic Landscape, the English landscape designer Nigel Dunnett [45] notes how "promoting diversity in vegetation is primarily reducing the vigour of dominant species - it is simply not enough to include a large number of species in a mix." Reducing the vigour of dominant species means reducing competition. Gilles Clément, a well-known French landscape architect, designer of the "garden of movement," of the André Citroën Park in Paris, is associated with ecological design in his mother country. In his "garden of movement," he claims to use natural energy, through processes like succession, to the benefit of gardens. He also seeks to promote species diversity. He explained his method as applied in his own garden in a presentation at the 
Musée national d'histoire naturelle in Paris, "Since it was a small vale and there was a serious possibility it would fill in (note: with trees), I introduced a management approach aimed at maintaining plant diversity. From my studies, I had learned that in our climate, unlike tropical regions, floristic diversity is better maintained by herbaceous rather than woody plants. (...) I tried to take into account the dynamic of the land's natural progression toward the forest climax by eliminating a closing in, that is, by removing a few trees that provided too much shade. But I also planted" [46]. In fact, he somehow freezes the succession picture at its most garden-like stage and assures it of an aesthetically pleasing biodiversity, fig. 2 . This case illustrates how ideas of nature as process as informed by ecology and nature conservation - cannot be fully applied in landscape and garden design.



Figure 2: $\quad$ Parc André Citroën, Paris, France, Photo Danielle Dagenais.

\section{The problem of representation of the passage of time}

Bowler [47], Prigogine and Stengers [48] and others have acknowledged the importance of the intrusion of time into scientific thought in the $18^{\text {th }}$ to $19^{\text {th }}$ centuries with respect to the emergence of time-based sciences like ecology. In the case of ecology, the passage from patterns to processes, from the world of plenitude and the fixity of species, to a world of evolution and natural selection was fundamental.

In one seminal article, Mozingo [49] states the necessity as well as the difficulty of providing visibility and temporality to ecological functions in the designed landscape. Temporality is seen as an obstacle to be skirted by integrating permanent structures, a symptom of the discomfort of the discipline with time [50]. Which time? Time can be the cyclical time of the seasons which brings germination, flowering or the shedding of leaves. This phenological time has been part of garden and landscape design for a long time: flowers, fruits, and colour of leaves have always captured human interest. What is new is the challenge of representing non-recurring process occurring on a longer ecological 
timescale. What is an ecological timescale? Succession could theoretically proceed over a 1-500 year or even 1000-year period, with one year being the period covering the germination and growth of desert annuals. Old field succession, the most common succession in landscape architecture, takes place within 200 years [51]. Most ecologists and nature conservationists work within a 100-year time frame [52].

How can visitors experience that time component of the landscape? Even competition, which results in altered vegetation patterns in a relatively short timescale, is unlikely to be detected by an occasional visitor to a garden or a even by an uninformed habitué. How then can one make succession visible? Ecologist use two methods of documenting succession: they either use historical data for a given site or they observe chronosequences, i.e. "adjacent plots of different stand age" [53]. So, one either tells the narrative of the stand, or one makes the visitors see the succession at different stages. Surprisingly the first strategy is the more common one in landscape architecture. Landscape architects resort to a more or less scientific or even poetic text narrative of the past process and sometimes future process as a mean of making the process visible (e.g. [54, 55] [56]) and whether it is the conscious intention or not, this is also a means of enhancing the cognitive aesthetic experience of their design [57], since narrative is the preferred way to order and render the experience of time [58, 59].

\section{Conclusion}

Although the findings of ecological sciences have been widely used by landscape and garden designers, the underlying opposite ideas of nature, nature of parts or of processes have been represented in landscapes with varied success. The aim of obtaining maximum biodiversity as a pattern is generally achieved, but it implies halting processes like competition and succession. Letting succession proceed implies naturalizing the landscape to the point where design is indistinguishable from nature; it also raises the problem of representing the time component of a process. Such representation is generally effected through a didactic or poetic narrative for the visitor. Chronosequences would be equally adequate but would involve more precise management of the succession than the underlying ideas of nature as process would permit. In all events, a finer definition of the nature with which designers are designing and more precise objectives in the design would help attune ecologists, nature conservationists, landscape designers, as well as the general public to a common understanding of the landscape.

\section{References}

[1] Worster, D., Nature's Economy, A History of Ecological Ideas, University Press: Cambridge, 1994.

[2] Dagenais, D., The Garden of Movement: Ecological Rhetoric in support of Gardening Practice, Studies in the History of Gardens and Designed Landscapes 24 (4), pp. 313-340, October-December, 2004. 
[3] Stiling, P., Ecology, Theories and Applications, 3rd ed. Prentice Hall: Upper Saddle River, New Jersey, 1999.

[4] Simberloff, Daniel. A Succession of Paradigms in Ecology: Essentialism to Materialism and Probabilism. Conceptual Issues in Ecology, ed. E. Saarinen, Pallas Paperbacks, D. Reidel Publishing Company: Dordrecht Holland, pp. 63-101, 1982.

[5] Cook, R. E., Do Landscapes Learn? Ecology's "New Paradigm” and Design in Landscape Architecture. Environmentalism in Landscape Architecture, ed. M. Conan. Dumbarton Oaks Research Library and Collection: Washington, D.C., pp.115-132, 2000.

[6] Mikkelson, G. M. Biological Diversity, Ecological Stability, and Downward Causation. Philosophy and Biodiversity, eds. M. Oksanen and J. Pietrarinen, Cambridge Studies in Philosophy and Biology, Cambridge University Press, Cambridge, pp.119-133, 2004.

[7] Odum, E. P., Principles of Ecology, 3rd ed., W.B. Saunder \& Co.: Philadelphia, 1971.

[8] Callicott, B. J., Crowder L. B. \& Mumford, K., Current Normative Concepts in Conservation Biology, Conservation Biology 13 (1), pp. 22-36, 1999.

[9] White, P.S. \& Bratton, S.P. After preservation: Philosophical and practical problems of change, Biological Conservation 18, pp. 241-255, 1980.

[10] Henderson, Norman. Wilderness and the Nature Conservation Ideal: Britain, Canada and the United States Contrasted, Ambio vol. 21 No. 6, pp. 394-399, 1992.

[11] Cooper, Nigel S. How natural is a nature reserve: An ideological study of British nature conservation landscapes, Biodiversity and Conservation 9, pp. 1131-1152, 2000.

[12] Swart, J.A.A., van der Windt, H.J., Keulartz, J., Valuation of Nature in Conservation and Restoration, Restoration Ecology, 9 (2), pp. 230-238, 2001.

[13] Oksanen, M. Biodiversity considered philosophically, Philosophy and Biodiversity, (eds.) M. Oksanen \& J. Pietarinen, Cambridge Studies in Philosophy and Biology, Cambridge: 27-54, 2004.

[14] Convention for Biodiversity, United Nations Environment Program, 1992. Online. < http://www.cbd.int/convention/convention.shtml> (consulted February 9, 2008).

[15] United Nation Environment Program, International Day for Biological Diversity, Secretariat for the Convention for Biodiversity, United Nations Environment Program. 2008. On line. < http://www.cbd.int/convention/ convention.shtml $>$ (consulted February 9, 2008).

[16] Barbour, M. G., Burk, J. H., Pitts, W. D., Gilliam, F. S., Schwartz, M. W., Terrestrial Plant Ecology, 3rd ed., Benjamin Cummings: Menlo Park, California, 1999.

[17] Hitchmough, J. \& Dunnett, N. Introduction to naturalistic planting in urban landscapes. The Dynamic Landscape, eds. N. Dunnett and J. Hitchmough, Spoon Press, London, 2004.

[18] Gaston, K.J. What is biodiversity? Biodiversity: a biology of numbers and difference, ed. K. J. Gaston, Blackwell Science, Oxford, 1996. 
[19] Ozenda, Paul. Les végétaux dans la biosphere, Doin Éditeurs, Paris, 1982.

[20] Ahern, J., Leduc, E.\& York, M.L. Biodiversity Planning and Design, Sustainable Practices, Island Press, Washington, 2006.

[21] United Nations Environment Program, op. cit.

[22] Hitchmough, J. \& Dunnett, N., op.cit.

[23] Nadenicek, D.J. \& Hastings, C.M., Environmental Rhetoric, Sophism, The Words and The Works of Landscape Architecture. Environmentalism in Landscape Architecture, ed. M. Conan, Dumbarton Oaks Research Library and Collection: Washington D.C., pp. 133-163, 2000.

[24] Luz, Heiner, The principle of dominant species, Topos, 37, December 2001, pp. 16-22, 2001.

[25] Atran, C., Cognitive Foundations of Natural History, Cambridge University Press, Cambridge, 1990.

[26] Lévi-Strauss, Claude, La pensée sauvage, Librairie Plon, Paris, 1962.

[27] Barsh, R.L., Indigenous knowledge and biodiversity, Cultural and Spiritual Values of Biodiversity, ed. Darrell Adison Posey, United Nations Environment Program: Nairobi, Kenya, pp. 73-76, 1999.

[28] Mace, G. \& Purvis, A., Evolutionary biology and practical conservation: bridging a widening gap, Molecular Ecology, 18, pp.9-19, 2008.

[29] Baridon, M. Les jardins, paysagistes, jardiniers, poètes, Robert Laffont: Paris, 1998, p.120.

[30] Den Hartog, E. \& Teune, C. Gaspard Fagel (1633-1688): his Garden and Plant Collection at Leeuwenhorst, Garden History, 30 (2), pp. 191-220.

[31] Wimmer, C.A. What style should we use for planting?, Topos 37, September 2001, pp.6-16, 2001.

[32] Jekyll, G. Wood and Garden, Antique Collectors' Club, London, 1899, reprinted 1981.

[33] Dagenais, D., op.cit.

[34] Kelsh, P., Constructions of American Forest: Four landscapes, four readings. Environmentalism in Landscape Architecture, ed. M. Conan, Dumbarton Oaks Research Library and Collection: Washington, D.C. pp. 163-185, 2000.

[35] Henderson, op. cit.

[36] Cooper, op.cit.

[37] Dunnett, N., The dynamic nature of plant communities. The Dynamic Landscape, eds. N. Dunnett and J. Hitchmough, Spoon Press, London, 2004, p. 102.

[38] Barbour et al., op. cit., p. 292.

[39] Leduc et al., op.cit.

[40] Swart et al., op. cit.

[41] Tallowin, J.R. B., Rook, A.J. \& Rutter, S.M. Impact of grazing management on the biodiversity of grasslands, Animal Science 81, pp. 93-198, 2005.

[42] Le Roy. L.G., Louis G. Le Roy: natuur, cultuur, fusie = nature, culture, fusion / samenstelling/compilation, eds. E. Boukema \& P. V. McIntyre, NAi Uitgevers/Publishers, Rotterdam, quote 39, 2002.

[43] Odum, E.P. op.cit. 
[44] Piet Vollaard, 'Time-based Architecture in Mildam', Oase, Tijdschrift voor architecture 2001, $\mathrm{n}^{\mathrm{o}}$ 57, 2001. Online. < http://www.stichtingtijd.nl/ fr/p_vollaard.php $>$ (consulted February 10, 2008).

[45] Dunnett, N., The dynamic nature of plant communities. The Dynamic Landscape, eds. N. Dunnett and J. Hitchmough, Spoon Press, London, 2004, pp. 97-114.

[46] Clément, G.. Jardins en mouvement, friches urbaines et mécanismes de la vie, Sauvages dans la ville, De l'inventaire naturaliste à l'écologie urbaine, Hommage à Paul Jovet (1896-1991), edited and revised, Éditions scientifiques du Muséum d'histoire naturelle, JATBA, Paris, 1999, p.158, 160, 161.

[47] Bowler, Peter J. ,The Earth Encompassed, A History of Environmental Sciences. New York: W.W. Norton et cie., 1992.

[48] Prigogine, I. \& Stengers, I., Entre le temps et l'éternité, Librairie Flammarion: Paris, 1992.

[49] Mozingo, L., The Aesthetics of Ecological Design: Seeing Science as culture, Landscape Architecture 16 (1): 46-59.

[50] Brzuszek, R.F. \& Clark, J. Are they getting it? Visitors respond to the Crosby Arboretum's Ecological Aesthetics, Landscape Architecture May 2007, pp. 78-85, 2007.

[51] Barbour et al. , op. cit., p. 276.

[52] Thompson, J.N. Rapid Evolution as an Ecological Process, TREE 13 (8), pp 339-332, 1998.

[53] Barbour et al., op.cit., p. 276.

[54] Morrison, D. A methodology for ecological landscape and planting designsite planning and spatial design, The Dynamic Landscape, eds. N. Dunnett and J. Hitchmough, Spoon Press, London, 2004, pp. 115-129.

[55] Brzuszek, R.F. \& Clark, J., op.cit.

[56] Dagenais, D., Ecologie, structuralisme et art des jardins dans l'œuvre de Gilles Clément (1943-), Ph.D. Thesis, University of Montreal: Montreal, 2007.

[57] Carlson, A. \& Berleant, A. Introduction: The Aesthetics of Nature, The Aesthetics of Natural Environment, eds. Al. Carlson \& A. Berleant, Broadview Press: Peterborough, Canada.

[58] Ricoeur, P., Temps et récit vol.1,2,3, Éditions du Seuil: Paris, 1984.

[59] Cauquelin, A., Petit traité du jardin ordinaire, Payot, Paris. 